\title{
FAKTOR-FAKTOR YANG MEMPENGARUHI KUALITAS PENGUNGKAPAN INFORMASI TANGGUNG JAWAB SOSIAL PERUSAHAAN DAN DAMPAKNYA TERHADAP COST OF EQUITY
}

\author{
Ekapratna Paradita *1 \\ ${ }^{1}$ Program Studi Akuntansi, Fakultas Ekonomi Universitas Muhammadiyah Buton, Baubau, Indonesia \\ e-mail: pratnaparadita@gmail.com
}

\begin{abstract}
ABSTRAK
Penelitian ini bertujuan untuk mengetahui pengaruh besaran perusahaan, profitabilitas, leverage, dan kualitas tata kelola perusahaan terhadap kualitas pengungkapan informasi tanggung jawab sosial perusahaan (CSR), serta dampak kualitas pengungkapan informasi tanggung jawab sosial perusahaan terhadap cost of equity. Populasi dalam penelitian ini adalah semua perusahaan yang mengikuti pemeringkatan IICG pada 2011-2016. Pengambilan sampel dilakukan dengan metode purposive sampling, dan menghasilkan sampel sebanyak 92 perusahaan. Pengumpulan data dilakukan dengan menganalisis laporan keuangan, laporan keberlanjutan dan laporan tahunan perusahaan dari situs web perusahaan sampel, situs web Bursa Efek Indonesia, dan majalah SWA Indonesia. Teknik analisis yang digunakan dalam penelitian ini adalah teknik analisis regresi berganda untuk mengukur pengaruh lebih dari satu variabel independen terhadap variabel dependen dan regresi sederhana. Hasil pengujian hipotesis dalam penelitian ini menunjukkan bahwa besaran perusahaan dan leverage tidak memengaruhi kualitas pengungkapan informasi tanggung jawab sosial perusahaan (CSR). Profitabilitas dan kualitas tata kelola perusahaan menunjukkan pengaruh positif yang signifikan terhadap kualitas pengungkapan informasi tanggung jawab sosial perusahaan (CSR). Hasil pengujian hipotesis juga menunjukkan bahwa kualitas pengungkapan informasi tanggung jawab sosial perusahaan (CSR) memiliki pengaruh negatif yang signifikan terhadap cost of equity.
\end{abstract}

Kata Kunci: Karakteristik Perusahaan, Tanggung Jawab Sosial Perusahaan, Tata Kelola Perusahaan, Cost of Equity

\section{ABSTRACT}

This study aims to determine the effect of company size, profitability, leverage, and quality of corporate governance on the quality of disclosure of corporate social responsibility (CSR) information, as well as the impact of the quality of disclosure of corporate social responsibility (CSR) information on the cost of equity. The population in this study was all companies that followed the IICG ranking in 2011-2016. Sampling was done by purposive sampling method, and generates a sample of 92 companies. Data collection was done by analyzing financial statements, sustainability reports and company annual reports from the sample company website, the Indonesia Stock Exchange 
website and SWA Indonesia magazine. The analysis technique used in this study is multiple regression analysis techniques to measure the effect of more than one independent variable on the dependent variable and simple regression. The results of hypothesis testing in this study indicate that the size of the company and leverage does not affect the quality of disclosure of information on corporate social responsibility (CSR). Profitability and quality of corporate governance show a significant positive effect on the quality of disclosure of corporate social responsibility (CSR) information. The result of hypothesis testing also show that the quality of information disclosure of corporate social responsibility (CSR) has a significant negative effect on the cost of equity.

Keywords: Company Characteristics, Corporate Social Responsibility, Corporate Governance, Cost Of Equity

\section{PENDAHULUAN}

Dana yang digunakan untuk membiayai aset dan operasi perusahaan direpresentasikan oleh modal finansial organisasi. Tingkat pengembalian yang diperlukan untuk mengkompensasi penyedia dana tersebut disebut biaya modal. Dalam mengevaluasi kinerja perusahaan biaya modal dapat menjadi dasar sedangkan untuk mengevaluasi investasi modal dapat menggunakan tingkat diskonto. Oleh karena itu, untuk pengambilan keputusan yang baik, perkiraan yang wajar tentang biaya modal perusahaan sangat penting untuk dilakukan. Utang dan ekuitas merupakan dua komponen utama modal organisasi. Biaya komponen ekuitas atau yang dikenal dengan cost of equity lebih sulit dipastikan, dan cost of equity adalah bagian yang dibahas dalam penelitian ini. Biaya ekuitas (cost of equity) perusahaan mewakili kompensasi yang diminta pasar sebagai ganti kepemilikan aset dan menanggung risiko atau dengan kata lain cost of equity mewakili kompensasi atas waktu yang dikorbankan dan risiko yang ditanggung oleh investor [1].

Pengungkapan informasi-informasi yang berkualitas dan relevan dengan kebutuhan para stakeholder dalam jumlah masif merupakan salah satu alternatif metode perusahaan untuk mengendalikan cost of equity. Semakin banyak informasi berkualitas yang diungkapkan kepada publik, maka akan mengakibatkan turunnya asimetri informasi dan juga mengakibatkan turunnya risiko yang diterima oleh investor [2]. Bagi banyak perusahaan, pasar saham memberikan insentif atau kompensasi lebih lanjut untuk terlibat dalam kegiatan Corporate Social Responsibility (CSR). Situasi masyarakat saat ini yang nampak semakin khawatir dengan CSR, oleh karena itu masyarakat sebagai pemegang saham yang relatif besar dan berkembang pesat, yang mana mereka secara khusus memengaruhi masalah etika 
terhadap keputusan investasi. Oleh sebab itu, investasi etis dengan menggunakan kriteria etis, sosial dan lingkungan dalam pemilihan dan pengelolaan portofolio investasi, umumnya terdiri dari saham perusahaan [3].

Penelitian Cuadrado-ballesteros et al. (2016) menemukan hal yang menarik yang membuktikan bahwa selain kualitas informasi keuangan, kualitas informasi sosial dan lingkungan juga mampu menurunkan asimetri informasi yang ada di pasar modal dan pada akhirnya menurunkan cost of equity [2]. Hal yang sama dikemukakan pada penelitian Reverte (2012) yang menunjukkan bahwa terdapat hubungan negatif yang signifikan antara kualitas pengungkapan CSR dan cost of equity [4]. Pengaruh negatif signifikan tersebut berdampak lebih nyata bagi perusahaan-perusahaan yang beroperasi pada lingkup industri yang peka terhadap lingkungan. Namun, di Indonesia sendiri, Nugroho (2012) yang meneliti mengenai pengungkapan informasi CSR dan pengaruhnya terhadap cost of equity menunjukkan hasil yang berbeda. Penelitian tersebut menyebutkan bahwa pengungkapan informasi CSR tidak berpengaruh terhadap cost of equity [5].

Kajian teori agensi menunjukkan bahwa keputusan perusahaan untuk lebih banyak mengungkapkan informasi pengungkapan sosialnya dilandasi oleh banyak faktor. Keputusan perusahaan untuk melakukan pengungkapan informasi sosialnya disebabkan oleh beberapa hal seperti kinerja ekonomi, visibilitas politik, biaya kontrak dan pengawasan, serta kinerja sosial perusahaan itu sendiri [6]. Riset terbaru yang dilakukan oleh Riset Centre for Governance, Institutions, and Organizations National University of Singapore (NUS) Business School (2016) menunjukkan fenomena kualitas pengungkapan CSR di Indonesia masih tegolong rendah dibandingkan negara tetangga seperti Thailand, Singapura, dan Malaysia [7]. Hal inilah yang mendasari pentingnya penelitian mengenai faktor-faktor yang berpengaruh tehadap kualitas informasi tanggung jawab sosial yang diungkapkan perusahaan sebagaimana yang telah disebutkan dalam kerangka teori agensi bahwa terdapat faktor-faktor yang menyebabkan perusahaan mengungkapkan informasi sosialnya. Di sisi lain, kualitas informasi tanggung jawab sosial yang diungkapkan perusahaan akan menurunkan risiko di pasar modal, dan akhirnya menyebabkan menurunnya cost of equity. Penelitian ini merupakan pengembangan dari penelitian Cuadrado-Ballesteros et al. (2016) yang hanya berfokus pada pengaruh kualitas informasi tanggung jawab sosial yang diungkapkan perusahaan terhadap cost of equity. Penelitian ini juga menggunakan variabel kualitas corporate governance perusahaan yang telah mengikuti program pemeringkatan kualitas tata 
kelola perusahaan di Indonesia dan variabel faktor-faktor yang mungkin dapat berpengaruh terhadap kualitas informasi tanggung jawab sosial yang diungkapkan perusahaan berkaitan dengan fenomena kualitas CSR di Indonesia, dan dampak kualitas informasi tersebut terhadap cost of equity.

\section{METODE PENELITIAN}

\subsection{Cost Of Equity}

Cost of equity adalah tingkat pengembalian yang diberikan sebagai kompensasi kepada investor (pemegang obligasi dan pemegang saham) atas modal yang mereka berikan [8]. Cost of equity diukur menggunakan metode CAPM (Capital Asset Pricing Model) dengan rumus:

$$
k=R_{f}+\beta\left(R_{M}-R_{f}\right)
$$

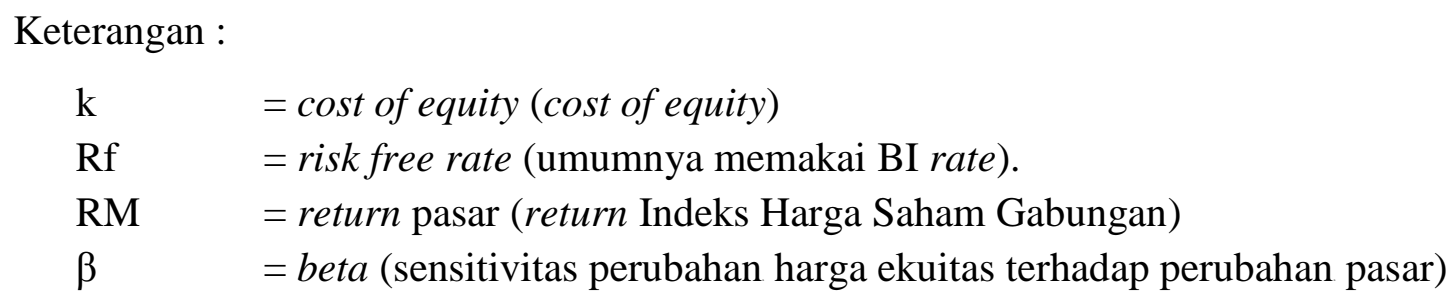

\subsection{Kualitas Pengungkapan Informasi Tanggung Jawab Sosial}

Cuadrado-Ballesteros et al. (2016) memperbaiki pendekatan penelitian-penelitian sebelumnya mengenai CSR. Penelitiannya menggunakan kuantifikasi indikator GRI sebagai syarat untuk mengungkapkan jumlah minimum indikator sesuai dengan tingkat aplikasi GRI A-C [2]. Berikut merupakan pengukuran kualitas pengungkapan informasi tanggung jawab sosial perusahaan:

Tabel 1. Indikator Kualitas Pengungkapan CSR

\begin{tabular}{|l|l|}
\hline \multicolumn{1}{|c|}{$\begin{array}{c}\text { Nilai Kualitas } \\
\text { Pengungkapan }\end{array}$} & \multicolumn{1}{c|}{ Jenis Laporan CSR } \\
\hline GRI $=0$ & Perusahaan yang tidak mengungkapkan informasi CSR \\
\hline GRI $=1$ & $\begin{array}{l}\text { Perusahaan yang mengungkapkan informasi CSR yang tidak } \\
\text { mengikuti panduan GRI }\end{array}$ \\
\hline GRI $=2$ & $\begin{array}{l}\text { Perusahaan yang mengungkapkan informasi CSR namun } \\
\text { masih pada tingkat atau level C panduan GRI, laporannya } \\
\text { masih sangat dasar. Lebih spesifik, laporan tersebut memuat } \\
\text { informasi tentang : } \\
\text { pengungkapan profil : nomor laporan } 1.1 ; 2.1-2.10 ; 3.1-3.8 ; \\
3.10-3.12 ; 4.1-4.4 ; 4.14-4.15 \text { (panduan GRI versi } 3)\end{array}$ \\
\hline
\end{tabular}




\begin{tabular}{|c|c|}
\hline & $\begin{array}{l}\text { Pengungkapan pada pendekatan manajemen : tidak diwajibkan } \\
\text { Indikator kinerja dan indikator kinerja pelengkap sektoral : } \\
\text { minimum pada } 10 \text { indikator kinerja, termasuk setidaknya satu } \\
\text { dari setiap kategori sosial, ekonomi dan lingkungan. Indikator } \\
\text { kinerja dapat dipilih dari sektor apapun,tetapi } 7 \text { dari } 10 \text { harus } \\
\text { berdasarkan pedoman asli GRI }\end{array}$ \\
\hline $\mathrm{GRI}=3$ & $\begin{array}{l}\text { Perusahaan yang mengungkapkan informasi CSR namun } \\
\text { masih pada tingkat atau level B panduan GRI, laporannya } \\
\text { lengkap. Lebih rinci, laporan tersebut memuat informasi } \\
\text { tentang: } \\
\text { Pengungkapan profil : nomor laporan 1.1; 1.2; 2.1-2.10; 3.1- } \\
\text { 3.13; 4.1-4.17 (lihat panduan GRI versi 3) } \\
\text { Pengungkapan pada pendekatan manajemen : untuk setiap } \\
\text { kategori indikator } \\
\text { Indikator kinerja dan dan indikator kinerja pelengkap } \\
\text { sektoral : minimum dari } 20 \text { indikator kinerja, termasuk } \\
\text { setidaknya } 1 \text { dari setiap kategori ekonomi, lingkungan, hak } \\
\text { azasi manusia, tenaga kerja, sosial, dan pertanggung jawaban } \\
\text { produk. Indikator kinerja dapat dipilih berdasarkan sektor } \\
\text { tambahan akhir apapun, akan tetapi 14 dari } 20 \text { harus } \\
\text { berdasarkan pedomanasli GRI. }\end{array}$ \\
\hline $\mathrm{GRI}=4$ & $\begin{array}{l}\text { Perusahaan yang mengungkapkan informasi CSR pada tingkat } \\
\text { atau level A panduan GRI, laporannya sangat lengkap dan } \\
\text { tersusun dengan baik. Secara lebih spesifik, laporan tersebut } \\
\text { memuat informasi tentang: } \\
\text { pengungkapan profil : } 1.1 ; 1.2 ; 2.1-2.10 ; 3.1-3.13 ; 4.1-4.17 \\
\text { (lihat panduan GRI versi } 3 \text { ) } \\
\text { Pengungkapan tentang pendekatan manajemen: untuk setiap } \\
\text { kategori indikator } \\
\text { Indikator kinerja dan indikator kinerja pelengkap sektoral: } \\
\text { menggabungkan setiap indikator pelengkap inti dan sektor }\end{array}$ \\
\hline
\end{tabular}

Sumber : Cuadrado-Ballesteros et al., (2016) ${ }^{[2]}$

\subsection{Besaran Perusahaan, Leverage \& Profitabilitas}

Penelitian ini mengukur besaran perusahaan berdasarkan total aset perusahaan. Kemudian, besaran perusahaan diproksikan dengan menggunakan log natural total aset dengan tujuan agar mengurangi fluktuasi data yang berlebih. Rasio leverage diukur dengan membagi rasio hutang tidak lancar perusahaan dengan ekuitas pemegang saham. Profitabilitas perusahaan diukur dengan kemampuan perusahaan menghasilkan laba pada periode waktu tertentu (ROA atau Return on Asset). 


\subsection{Corporate Governance}

Tiga tingkatan pemeringkatan CGPI terbaik didesain berdasarkan pada tingkat kepercayaan, pengukuran skor penerapan tata kelola perusahaan ialah sebagai berikut:
a. Cukup terpercaya (Skor 55-69,99)
b. Terpercaya (Skor 70-84,99)
c. Sangat terpercaya (85-100)

\subsection{Populasi dan Sampel Penelitian}

Populasi pada penelitian ini adalah seluruh perusahaan yang termasuk dalam pemeringkatan IICG. Untuk pemilihan sampel dilakukan melalui metode purposive sampling. Kriteria yang digunakan dalam penentuan sampel ini perusahaan yang telah mengikuti sejumlah penilaian yang dilaksanakan oleh Indonesia Institute for Corporate Governance (IICG) pada periode 2011-2016, penilaian tersebut dipublikasikan dalam majalah SWA dan terdaftar di Bursa Efek Indonesia.

\subsection{Metode Analisis}

Analisis regresi linear berganda digunakan untuk menguji hipotesis dalam penelitian ini. Analisis regresi linear berganda dapat digunakan untuk mengukur pengaruh lebih dari satu variabel independen terhadap variabel dependen [9]. Model regresi dirumuskan sebagai berikut:$$
\mathrm{SRQ}=\alpha+\beta 1 \mathrm{SIZE}+\beta 2 \mathrm{PROF}+\beta 3 \mathrm{LEV}+\beta 4 \mathrm{CGPI}+\varepsilon
$$$$
\text { EQUITY } \quad=\alpha+\beta \text { SRQ }+\varepsilon
$$

Keterangan :

Equity : Cost of equity

SRQ : Social and environmental quality/ Kualitas pengungkapan informasi tanggung jawab sosial.

SIZE : Besaran perusahaan

LEV : Leverage

PROF : Profitabilitas

CGPI : Corporate Governance Perception Index
} 


\section{HASIL DAN PEMBAHASAN}

\subsection{Hasil Penelitian}

Tabel 2. Tabel Uji Asumsi Klasik \& Uji Hipotesis

\begin{tabular}{|c|c|c|c|c|c|c|c|c|}
\hline \multicolumn{2}{|c|}{ Model } & \multirow{2}{*}{$\frac{\text { B }}{.105}$} & \multirow{2}{*}{$\begin{array}{l}\begin{array}{l}\text { Std. } \\
\text { Error }\end{array} \\
2.455\end{array}$} & \multirow[t]{2}{*}{ Beta } & \multirow{2}{*}{$\frac{\mathbf{T}}{.043}$} & \multirow{2}{*}{$\frac{\text { Sig. }}{.966}$} & \multirow[t]{2}{*}{ Tolerance } & \multirow[t]{2}{*}{ VIF } \\
\hline 1 & (Constant) & & & & & & & \\
\hline & Size & -.185 & .113 & -.313 & -1.636 & .105 & .250 & 4.005 \\
\hline & Profit & .044 & .018 & .272 & 2.430 & .017 & .733 & 1.364 \\
\hline & Lev & .011 & .046 & .036 & .229 & .820 & .375 & 2.667 \\
\hline & CGPI & .093 & .027 & .495 & 3.454 & .001 & .466 & 2.242 \\
\hline & \multicolumn{3}{|c|}{$\begin{array}{l}\text { Kolmogorov-Smirnov Z } \\
\text { Asymp. Sig. (2-tailed) }\end{array}$} & \multicolumn{5}{|c|}{$\begin{array}{l}1.237 \\
.094 \\
\end{array}$} \\
\hline & \multicolumn{3}{|c|}{ Durbin-Watson } & \multicolumn{5}{|c|}{2.016} \\
\hline & \multirow{2}{*}{\multicolumn{3}{|c|}{$\begin{array}{l}\text { F } \\
\text { Sig }\end{array}$}} & \multicolumn{5}{|c|}{5.519} \\
\hline & & & & & & & & \\
\hline & \multicolumn{8}{|c|}{ Adj. R Square 0.166} \\
\hline
\end{tabular}

Sumber : Data sekunder yang diolah, 2018

Hasil pengujian variabel ditunjukkan oleh Tabel 2 di atas. Pengujian terhadap variabel besaran perusahaan menghasilkan t hitung sebesar -1,636 dengan signifikansi 0,105. Dengan demikian, besaran perusahaan tidak memiliki pengaruh terhadap kualitas pengungkapan CSR. Hasil pengujian variabel profitabilitas menunjukkan nilai t hitung lebih besar dibandingkan nilai t tabel yaitu 2,015 dengan signifikansi 0,017, hasil tersebut menunjukkan bahwa profitabilitas berpengaruh positif terhadap kualitas pengungkapan CSR. Hasil pengujian variabel leverage memiliki nilai t hitung yang sebesar -0,229 dengan signifikansi 0,820 yang berarti leverage tidak berpengaruh terhadap kualitas pengungkapan CSR. Hasil pengujian variable CGPI memiliki nilai t hitung sebesar 3,454 dan signifikansi 0,001. Hasil tersebut menunjukkan bahwa kualitas corporate governance berpengaruh positif terhadap kualitas pengungkapan CSR. 
Tabel 3. Tabel Uji Asumsi Klasik \& Uji Hipotesis Model Persamaan II

\begin{tabular}{|c|c|c|c|c|c|c|}
\hline \multicolumn{2}{|c|}{ Model } & \multirow{2}{*}{$\frac{\text { B }}{.214}$} & \multirow{2}{*}{$\begin{array}{l}\begin{array}{l}\text { Std. } \\
\text { Error }\end{array} \\
.036\end{array}$} & \multirow[t]{2}{*}{ Beta } & \multirow{2}{*}{$\frac{\mathbf{T}}{5.862}$} & \multirow{2}{*}{$\frac{\text { Sig. }}{.000}$} \\
\hline 1 & (Constant) & & & & & \\
\hline & SRQ & -.038 & .014 & -.273 & -2.691 & .008 \\
\hline & \multicolumn{2}{|c|}{$\begin{array}{l}\text { Kolmogorov-Smirnov Z } \\
\text { Asymp. Sig. (2-tailed) }\end{array}$} & \multicolumn{2}{|c|}{$\begin{array}{l}1.062 \\
.210\end{array}$} & & \\
\hline & \multicolumn{2}{|c|}{ Durbin-Watson } & \multicolumn{2}{|c|}{1.814} & & \\
\hline
\end{tabular}

Adj. R Square 0.064

Sumber : Data sekunder yang diolah, 2018

Tabel 3 hasil uji parsial (t-test) diketahui bahwa nilai koefisien kualitas pengungkapan CSR adalah -0,038, menunjukkan koefisien negatif dengan nilai t hitung sebesar -2,691 dan signifikansi 0,008. Hasil ini menunjukkan bahwa kualitas pengungkapan informasi tanggung jawab sosial perusahaan memiliki pengaruh negatif terhadap cost of equity.

\subsection{Pembahasan}

Hasil uji variabel menunjukkan bahwa besaran perusahaan tidak berpengaruh terhadap kualitas pengungkapan CSR. Hasil ini tidak bertentangan dengan teori agensi yang menyatakan bahwa perusahaan yang memiliki visibilitas politik yang tinggi atau identik dengan besaran perusahaan yang besar, mempunyai kecenderungan untuk menurunkan biaya politisnya dengan mengungkapkan informasi sosial yang lebih baik dan lebih luas. Hasil ini mendukung penelitian Nawaiseh et al (2015) yang menunjukkan bahwa besaran perusahaan tidak berpengaruh terhadap kualitas pengungkapan CSR [10].

Hasil uji variabel menunjukkan bahwa profitabilitas berpengaruh positif terhadap kualitas pengungkapan CSR, diterima. Hasil ini mendukung teori agensi yang menyebutkan bahwa manajer perusahaan profitable cenderung lebih banyak memberikan informasi untuk mendukung kelanjutan posisi dan pengaturan kompensasi mereka sendiri. Kerangka teori agensi juga menyebutkan bahwa tuntutan pemegang saham dalam pengungkapan informasi sosial perusahaan sama halnya dengan tuntutan pemegang saham agar perusahaan dapat memberikan keuntungan yang tinggi [6]. Hasil penelitian ini sesuai dengan penelitian Ali (2017) yang menunjukkan bahwa salah satu faktor yang mendorong agenda pelaporan CSR di negara maju dan berkembang ialah karakteristik perusahaan seperti profitabilitas [11]. 
Hasil penelitian ini juga sesuai dengan Penelitian Lu \& Abeysekera (2014) yang menemukan bahwa profitabilitas merupakan determinan dan memiliki pengaruh positif terhadap kualitas pengungkapan informasi tanggung jawab sosial perusahaan [12].

Hasil uji variabel menunjukkan bahwa leverage tidak memiliki pengaruh terhadap kualitas pengungkapan CSR. Hasil ini tidak mendukung teori agensi yang memprediksi semakin tinggi rasio leverage maka perusahaan cenderung mengungkapkan lebih banyak informasi dikarenakan tingginya biaya agensi perusahaan. Tidak adanya perbedaan yang cukup signifikan antara rasio leverage yang perusahaan yang tinggi maupun rendah dalam kualitas pengungkapan CSR perusahaan dapat menyebabkan tidak berpengaruhnya leverage terhadap kualitas pengungkapan CSR perusahaan. Hasil ini mendukung penelitian Untari (2010) yang menunjukkan bahwa leverage tidak memiliki pengaruh terhadap pengungkapan informasi sosial [13].

Hasil uji variabel menyatakan bahwa kualitas corporate governance berpengaruh positif terhadap kualitas pengungkapan CSR, diterima. Hasil pengujian sesuai dengan teori agensi yang menjelaskan bahwa tata kelola perusahaan merupakan seperangkat mekanisme untuk menurunkan risiko agensi yang disebabkan asimetri informasi. Tata kelola melibatkan mekanisme internal dan turut serta melibatkan mekanisme eksternal. Tanggung jawab sosial sebagai komitmen perusahaan kepada masyarakat merupakan bagian dari mekanisme eksternal tata kelola perusahaan [14]. Hasil penelitian ini mendukung penelitian Liu \& Zhang (2017) yang menyatakan bahwa perusahaan yang memiliki tata kelola yang berkualitas cenderung mengungkapkan tanggung jawab sosial yang berkualitas untuk mempertahankan reputasi perusahaan dan mewujudkan pembangunan perusahaan yang berkelanjutan [15].

Hasil uji variabel menyatakan bahwa kualitas pengungkapan CSR berpengaruh negatif terhadap cost of equity, diterima. Hasil pengujian ini sesuai dengan penjelasan teori agensi bahwa adanya asimetri informasi memunculkan masalah agensi dan meningkatkan risiko yang diterima oleh para pemegang saham. Risiko yang tidak dapat diobservasi dapat dikurangi dengan keterbukaan pengungkapan dan juga pengurangan biaya modal melalui banyak mekanisme. Keterbukaan juga mengurangi asimetri informasi dikalangan investor maupun antara manajer dan investor. Hasil ini mendukung penelitian Reverte (2012) dan El Ghoul et al. (2011) yang menunjukkan bahwa terlibat dalam praktik CSR berkualitas tinggi dapat mengurangi cost of equity dengan mengurangi sejumlah informasi asimetri, kemudian 
selanjutnya mengkomunikasikan informasi tersebut kepada para investor yang pada akhirnya akan menurunkan risiko ketidakpastian [16].

\section{KESIMPULAN}

Penelitian ini bertujuan untuk mengetahui pengaruh dari besaran perusahaan, profitabilitas, leverage, dan kualitas corporate governance terhadap kualitas pengungkapan informasi tanggung jawab sosial (CSR), serta dampak kualitas pengungkapan informasi tanggung jawab sosial (CSR) terhadap cost of equity pada perusahaan yang mengikuti pemeringkatan IICG. Dari hasil pengujian hipotesis, diketahui bahwa perusahaan dengan profitabilitas tinggi cenderung memiliki CSR yang berkualitas. Temuan lainnya mengindikasikan bahwa semakin baik corporate governance yang ada pada perusahaan, maka kualitas informasi sosial yang diungkapkan oleh perusahaan juga semakin baik. Hasil ini berbeda dengan pengaruh besaran perusahaan dan leverage terhadap kualitas pengungkapan CSR. Hasil penelitian membuktikan bahwa besar kecilnya besaran perusahaan dan tinggi rendahnya leverage tidak memengaruhi kualitas pengungkapan informasi CSR perusahaan. Penelitian ini juga menguji pengaruh kualitas pengungkapan informasi tanggung jawab sosial perusahaan (CSR) terhadap cost of equity. Hasil penelitian menunjukkan bahwa kualitas pengungkapan informasi tanggung jawab sosial perusahaan (CSR) berpengaruh negatif terhadap cost of equity. Hal ini mengindikasikan bahwa pengungkapan CSR yang berkualitas dapat membantu mengurangi risiko yang tidak dapat diobservasi dan karenanya dapat mengurangi cost of equity.

\section{DAFTAR PUSTAKA}

[1] Cotner, J. S. \& Fletcher, H. D. 2000. Computing the cost of capital for privately held firms. American Business Review, 18(2), 27-33.

[2] Cuadrado-Ballesteros, B., Garcia-Sanchez, I.-M. \& Martinez Ferrero, J. 2016. How are corporate disclosures related to the cost of capital? The fundamental role of information asymmetry. Management Decision, 54(7), pp.1669-1701.

[3] Cowton, C. J. 1994, The Development of Ethical Investment Products, in A. R. Prindl and B. Prodhan (eds.).ACT Guide to Ethical Conflicts in Finance (Blackwell, Oxford), pp. 213-232. 
[4] Reverte, C., 2012. The Impact of Better Corporate Social Responsibility Disclosure on the Cost of Equity Capital. Corporate Social Responsibility and Environmental Management, 19(5), pp.253-272.

[5] Nugroho, Stephanus K.A. 2012. Pengaruh Corporate Social Responsibility Disclosure Terhadap Cost Of Equity Capital. Skripsi Universitas Indonesia.

[6] Belkaoui, A. \& Karpik, P.G. 1989. Determinants of the Corporate Decision to Disclose Social Information. Accounting, Auditing \& Accountability Journal, 2(1).

[7] Suastha, Riva D. 2016. Riset Temukan Kualitas CSR Perusahaan Indonesia Rendah diakses pada tanggal 10 Januari 2018 dari https://www.cnnindonesia.com/nasional/20160721074144-20-146030/risettemukan-kualitas-csr-perusahaan-indonesia-rendah

[8] Ghozali, Imam. 2013. Aplikasi Analisis Multivariate dengan Program IBM SPSS 21 Update PLS Regresi. Semarang: Badan Penerbit Universitas Diponegoro.

[9] Schlegel, Dennis. 2015. Cost-of-Capital in Managerial Finance; An Examination of Practices in the German Real Economy Sector. Springer International Publishing (1)

[10] Nawaiseh, M. E., Boa, S. S. A., \& El-shohnah, R. A. Z. Y. 2015. Influence of Firm Size and Profitability on Corporate Social Responsibility Disclosures by Banking Firms (CSRD): Evidence from Jordan. Journal of Applied Finance and Banking, 5(6), 97

[11] Ali, W., Frynas, J. G., \& Mahmood, Z. 2017. Determinants of Corporate Social Responsibility (CSR) Disclosure in Developed and Developing Countries: A Literature Review. Corporate Social Responsibility and Environmental Management, 24(4), 273-294.

[12] Lu, Y. \& Abeysekera, I. 2014. Stakeholders Power, Corporate Characteristics, and Social and Environmental Disclosure : Evidence from China. Journal of Cleaner Production, 64, pp.426-436.

[13] Untari, Lisna. 2010. Effect on Company Characteristics Corporate Social Responsibility Disclosure in Corporate Annual Report of Consumption Listed in Indonesia Stock Exchange. Undergraduate Program, Economy Faculty, Gunadarma University. http://www.gunadarma.ac.id. 
[14] Ruangviset, J., Jiraporn, P. \& Kim, J.C. 2014. How does Corporate Governance Influence Corporate Social Responsibility? Procedia - Social and Behavioral Sciences, 143, pp.1055-1057.

[15] Liu, X. \& Zhang, C. 2017. Corporate Governance, Social Responsibility Information Disclosure, And Enterprise Value In China. Journal of Cleaner Production, 142, pp.1075-1084.

[16] El Ghoul, S., Guedhami, O. Kwok, C. C., \& Mishra, D. R. 2011. Does Corporate Social Responsibility Affect The Cost of Capital?. Journal of Banking \& Finance, 35(9), 2388-2406. 